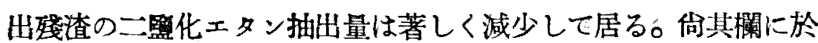
て抽出分の數字に+符號の附けてあるものは二監化エタン抽出後

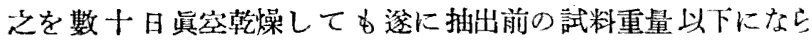
ず,夫々の\%重量篔加を示したものである。斯かる事實は國座 NN 系のゴムが其內部に多くの網狀結合を有し，之を酒情性カり抽出 すると其中に微細な毛管的細隙を生じ，斯かる場所に包含された

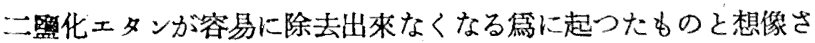

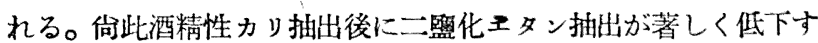
る事賽はブタヂェン・アクリルニトリル重合物が其末端を解﨎せ る乳化劑の酸性分或はアルカり性分を以て飽和して居り，之を抽 出，除去すると更に其處で新たに三次元的結合が進行する鹪であ ると考へられる。斯かる考へ方に依ても國座品が比較的重合度低 く, 三次元的結合が多い事實は, 過剩の（或は不適當な）乳化瓣，
重合劑を使用して居る點に基因するものと推測される。

\section{5. 推論}

以上の實驗結果孙ら國産の $\mathrm{BN}$ 采合成ゴム品質向上の方針と して次の諸噸が考へられる。

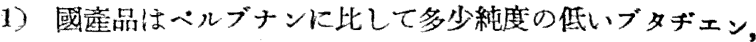
アクリルニトリルを原料とし，之に過剩の乳化劑，重合劑を加一 て重合を行つて居る傾向が䇲へる。

2) 國崖品は孚化方法, 重合方法, ラテ,クスの凝固法, 洗淮 法等に佾多くの改良の飴地が殘されて居る樣に見られる。

3）資材關係と關聯ずる事項ではあるが乳化濟の種類, 品質, 重合㸉との組合せ等に就ては更に嚴密な檢討，選擇が必要であ る。

\title{
(403) クロトンアルコールの脫水によるブタヂエンの合成
}

永井宏

\section{1. 緒霉}

R. B. Earle (J.Am. Chem. Soc., 1914, 36, 983) は 1.3-ブチ レングリコールの 2 分子脫水によりブタヂエンを生成せしめる際, 分解生成物中にクロトンアルコールの存在を認め,ブタヂェン生成 の反雔は次の二階程より践るものと推定した。

(1) $\mathrm{CH}_{3}-\mathrm{CH}-\mathrm{CH}_{2}-\mathrm{CH}_{2} \mathrm{OH}$

$\mathrm{OH}$

$$
\longrightarrow \mathrm{CH}_{3}-\mathrm{CH}=\mathrm{CH}-\mathrm{CH}_{2} \mathrm{OH}+\mathrm{H}_{2} \mathrm{O}
$$

(2) $\mathrm{CH}_{3}-\mathrm{CH}=\mathrm{CH}-\mathrm{CH}_{2} \mathrm{OH}$

$$
\longrightarrow \mathrm{CH}_{2}=\mathrm{CH}-\mathrm{CH}=\mathrm{CH}_{2}+\mathrm{H}_{2} \mathrm{O}
$$

郎ちグリュールは先づ 1 分子脫水せられてクロトンテルェール となり，更に水 1 分子を失つてブタギェンを生ずるのであつて後 者の反㮣は極めて速に行はれるのであると述へてるる。この說に從 一ばクロトンアルュールの脫水によつてブタヂェンを合成する反 應は極めて容易に行はれることななる

Kyriakides (J.Am. Chem. Soc., 1914, 36, 986) はクロトンテ ルコールを $400 〜 450^{\circ} \mathrm{C}$ で脱水することによつて容易てブタヂェン の得られることを報告してるるが，何等货驗的な記载がない。文 Bayer \& Co. の特許（D.R.P. 263016；B.P. 2777）によればク ロトンアルコールをカリウム、或はトルイヂンの重硫酸繁，無水街

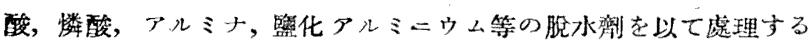
ことイよつて容易にプタヂェンが生成されると述べられてるる。

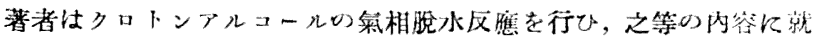
て檢討を加いることっした。

\section{2. 試}

料

實驗に使用したクロトンアルコールは W. G. Young, W. H. Hartung and F. S. Crossley 等の方法 (J.Am. Chem. Soc., 1936,

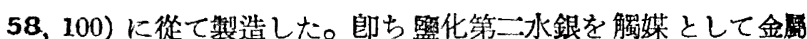
アルミ゙ニムとイソプロピルアルコールとよりアルミ゙ウムイソ プロピラートを造り，次にイソプロピルアルコールを溶劑として 之にっロトンアルデヒドを作用せしめた。生成したクロトンアル コールは蒸溜を繰返して精製し $117 \sim 122^{\circ} \mathrm{C}$ の溜分を探取した。 その比重は $d_{4}^{20}=0.846$, 屈折率は $n_{\mathrm{D}}^{20}=1.4278$ であつて交獻值と 極めて近似してるる。

\section{3. 赛 驗 方 法}

本賽驗に用ひた裝置は 1.3 -ブチレングリコールの脱水反應に 用ひた裝置 (本誌，昭和 $16,14,122$, 第 1 圆參照) と同樣であ つて，クロトンアルコールを一定速度の下に加熱觸媒中を通過せ しめて脫水反應を起さしめ, 生成するガスの總量を測定し, 且そ の組成を分析した。又副反應によつて生成寸る夜狀物質の量的關 係，組成等に就ても考察を加へた。

ガス分析の方法は前揭グリコール脫水の害驗の場合と同樣であ る。

\section{4. 觸媒}

䆩驗に用ひた觸媒は 1.3-ブチレングリコールよりブタヂェン を生成せしめる際に脫水解媒として比較的良好な成績を示した头 の如き組成の 2 種の混合觛媒を用ひた。

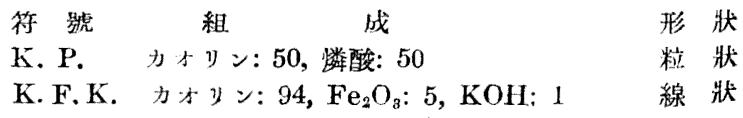

份觸媒の製法に就ては本誌，昭和 16，44，124を參照せられ度 w。

\section{5. 實驗及び考察}

反應管として直丝 $2.5 \mathrm{~cm}$ の透明水晶管を用ひ，この中に能㖼 
第 1 表 生成ガスの数成及びブタチェンの收率

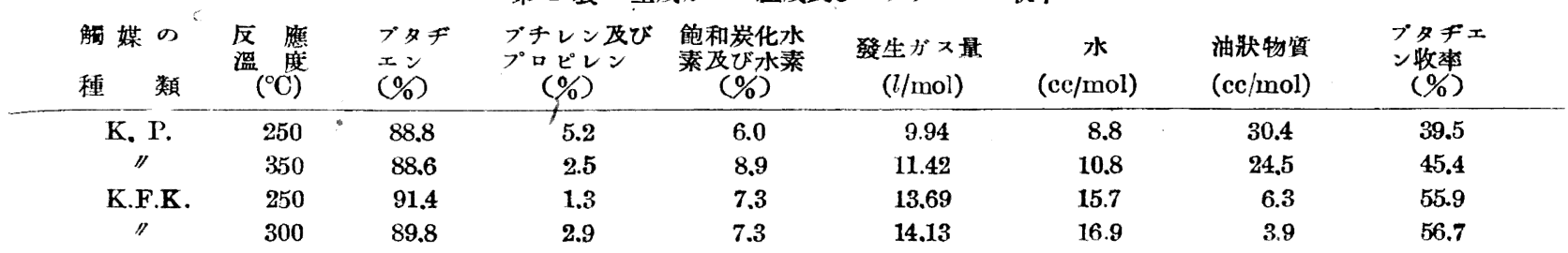

註：本表中水及び油狀物質量は反應中逸散せるるのあるを以て装密な值ではない。

を $15 \mathrm{~cm}$ の長さに滿した。反應管內の塺力は $730 \mathrm{mmHg} に$ 保ち， クロトンアルコール供給速度は凡て $12 \mathrm{cc} / \mathrm{hr}$ とした。生成ガス の組成及び其他の實驗成績は第 1 表の如くである。

以上の結果によれば生成ガス中のブタヂェン含有量は雨觸媒の 場合共極めて高い。然しガスの發生量はカオリン $-\mathrm{Fe}_{2} \mathrm{O}_{3}-\mathrm{KOH}$ 混合觸媒の方が遙に多く, 從てブタヂェンの收率も高い。カオリ ン一橉酸混合觸媒の場合には分離される水の量が少い點から見て 油狀物質は主として脫水以前に生成したるのと思はれるが，カオ リン- $\mathrm{Fe}_{2} \mathrm{O}_{3}-\mathrm{KOH}$ 觸媒の場合には水の生成が理論量に近い點か ら見て油狀物質は主としてブタヂェンから生成しためのと思はれ る。而して其生成量は前者に比し著しく少い。

カオリンー橉酸混合觸媒を用ひて $350^{\circ} \mathrm{C}$ に於て生成した油狀物 質の各溜分の量的割合及び屈折率は第 2 表の如くである。

\section{第 2 表 油狀物質 2 性質}

\begin{tabular}{|c|c|c|c|c|}
\hline$=\left({ }^{\circ} \mathrm{C}\right)$ & $75 \sim 95$ & $95 \sim 110$ & $110 \sim 130$ & $130 \sim 140$ 殘 \\
\hline 溜分の量 (0) & 8.4 & 12.5 & 45.8 & $16.7 \quad 16.6$ \\
\hline 2 & $\ldots$ & 1.4173 & 1.4220 & 1.4280 \\
\hline
\end{tabular}

油狀物筫は主として沸點 $110 \sim 130^{\circ} \mathrm{C}$ のものから成つて居り， 又各溜分の屈折率は 1.3-ブチレングリコールからブタヂェンを 得る際に生成される油狀物質の各溜分の値 (本誌, 昭和 17,45 , 554）とよく近似してるる。この事賽から見れぱ 1.3-ブチレング リュールからブタヂェンを生成つる反應に於て中間體としてクロ／ トンアルコールを生ずると云ふ考へが首肖出來る。

本實驗に於けるブタヂェンの收率は比較的好條件の場合でむ約
57\%であつて，この反應も多くの副反應を件ひ單純な反應として 進行しないのは意外である。一般に飽和の 1 價アルコールより 1 分子脫水を行ふことによつて二重結合 1 個を有する炭化水素を生 成せしめる反應は極めて容易であつ?理論値に近い收率を以て行 はれることはよく知られてるる。然し乍ら不飽和の1價アルコー ルより 1 分子脫水により二重結合 2 個を有する炭化水素を生成 せしめる際には極めて複雜な副反應を件ふことが本實驗の結果か ら認めることが出來る。

\section{6. 要 旨}

クロトンアルコールの氣相脫水によりブタヂェンを生成せしめ る反應を行つた結果次の如き事實を認めた。

(1) 脫水によつて生成するガス中のブタヂェン含有量は約 90\% 內外であるが, 發生するガスの總量は觸媒の種類及び反應の 條件によつて異る。

（2）脫水の際に生成する油狀物質の組成は 1.3-ブチレッグ リコールの 2 分子脫水によりブタヂェンを合成する際に生成する 油狀物質の組成と近似してるる點から,グリコール脫水反礁に於 ては中間體としてクロトンアルコールが生成されるものと推定さ れる。

（3）ブタヂェンの收集は比較的好條件の場合でも約 $57 \%$ で あつて複雜な副反應の件ふことが認められる。

附記：本研究は井上春成博士の御愁篤なる御指導の下に行つな ものでする。又识驗の一部は河合宗夫學士及び渡㟫秀雄涺の御捘助 を得た。这に之等の諸氏に對し深厚なる謝意を表する。 